\title{
Leaf number, water stress and carbon nutrition effects on poplar leaf growth
}

\author{
J.P. Gaudillère*
}

Laboratoire de Chimie Biologique et de Photophysiologie, INRA, 78850 Thiverval, France

\section{Introduction}

The final area of a leaf is described by the number and the mean size of epidermal cells. Water stress, nitrogen, light and temperature have been demonstrated to affect foliage development. These factors act at different levels in the process of leaf production. The main susceptible physiological mechanisms are cell division and differentiation in the apex and in the unfolding leaf. It has been shown that carbon nutrition has a very significant effect on the duration of the cell division phase. When the leaf begins to export carbon, cell divisions end (Dale and Milthorpe, 1983). Plant-water relations also play a major role through their effects on cell expansion (Lockhart, 1965). Cell divisions are less affected by water stress (Clough and Milthorpe, 1975).

These experiments were designed to specify water availability and carbon nutri- tion effects on the number and the mean size of epidermal poplar leaves.

\section{Materials and Methods}

\section{Plant production}

The experiments were carried out on Populus euramericana var. 1214. Cuttings grew on peat and mineral nutrients were supplied as low solubility fertilizer (Osmocote, 18/11/10). Plants were watered daily with tap water. Growth conditions were: metal halide lamps $(200 \mu \mathrm{mol}$ $\left.\mathrm{m}^{-2} \cdot \mathrm{s}^{-1}\right)$; light period: $16 \mathrm{~h}$, day and night temperature and humidity: $20^{\circ} \mathrm{C}$ and $70 \%$.

\section{Anatomical measurements}

Areas of attached leaves were measured by the dot grid method (Bouchon, 1975). The number and the size of epidermal cells were measured on prints (Austin et al., 1982) at the final harvest.

\footnotetext{
"Present address: Station de Physiologie Végétale, INRA, BP 131, 33140 Pont-de-la-Maye, France.
} 


\section{Experimental conditions}

Long-term stress was obtained by lowering the daily watering to $10 \%$ of the amount of transpired water at the beginning of the experiment. After $20 \mathrm{~d}$, full watering was applied. $\mathrm{CO}_{2}$ enrichment was carried out in a gas-tight growth chamber with the same other growing conditions. $\mathrm{CO}_{2}$ concentration was controlled and monitored with an IRGA and the hourly $\mathrm{CO}_{2}$ uptake or evolution was computed (Lapierre et al., 1983).

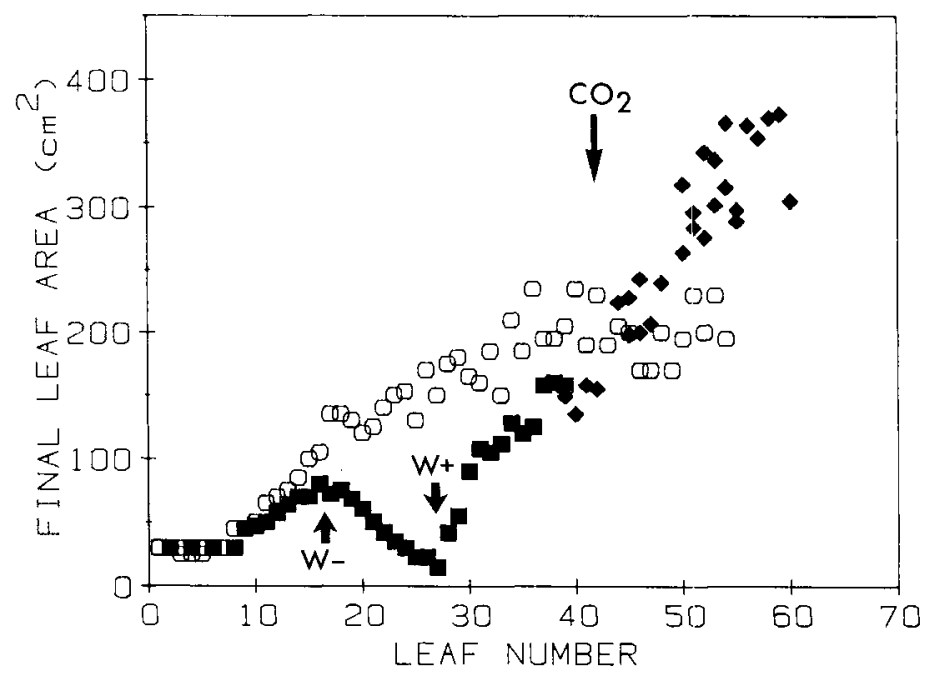

Fig. 1. Final leal area of poplar clone 1214. O: grown under standard conditions; $\square$ : subjected to a water limitation between $\mathrm{W}-$ and $\mathrm{W}_{+} ;$: subjected to $\mathrm{CO}_{2}$ enrichment in the air.

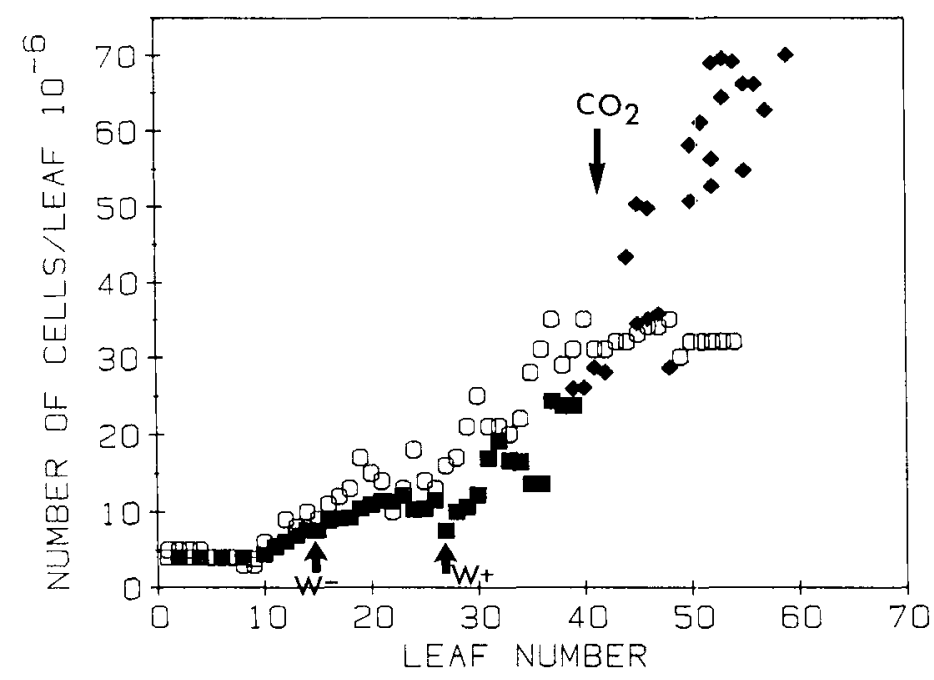

Fig. 2. Number of epidermal cells in adult leaves of poplar clone 1214. Same symbols as in Fig. 1. 


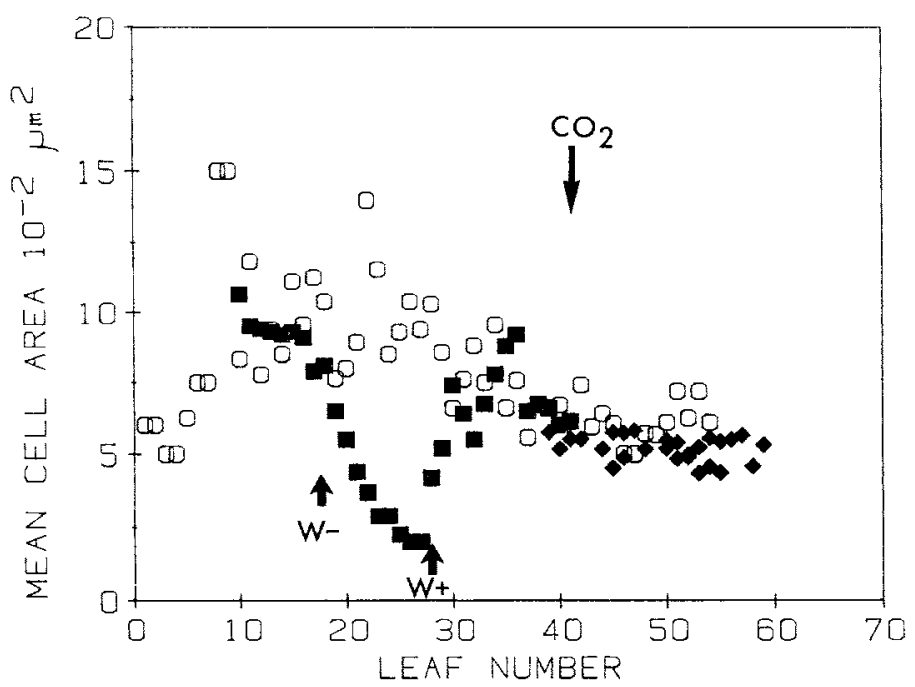

Fig. 3. Mean epidermal cell area of adult leaves of poplar clone 1214. Same symbols as in Fig. 1.

\section{Results}

Leaf number (LN) effect

Under our growth conditions, the final leaf area of successive leaves on control plants increased until a constant value of $200( \pm 10) \mathrm{cm}^{2}$, (Fig. 1). The number of cells per leaf increased with $L N$ (Fig. 2). The mean cell size was lower in preexisting leaves than in the bud (Fig. $3 ; L N$ 1-7). Newly initiated leaves had initially large epidermal cells (LN 8-25). Then a regular decrease of the mean leaf area was observed.

\section{Water stress effect}

Reduction of watering provoked water stress. Leaf growth was inhibited until rewatering. The final leaf size was very significantly decreased (Fig. 1). This decrease was entirely explained by the mean size of the cells (Fig. 3). The number of cells per leaf (Fig. 2) was hardly affected by the treatment. With the rewa- tering, cell divisions and expansion started again. Newly expanded leaves presented the same anatomical characteristics as the control (Figs. 2 and 3 ).

\section{Effect of carbon nutrition}

A $40 \%$ increase in the photosynthetic $\mathrm{CO}_{2}$ assimilation rate of the trees was produced by $\mathrm{CO}_{2}$ enrichment $\left(600 \mu \mathrm{l}^{-1}\right)$ of the air. The final leaf area was highly stimulated by this treatment (Fig. 1). The main growth component affected by the increase of the carbon nutrition was the number of cells per leaf, which doubled (Fig. 2). The mean size of the cells was not affected (Fig. 3).

\section{Discussion}

Water stress and carbon nutrition significantly change the final area of leaves. It is well known that the water supply 
reduces the expansive growth of leaf cells (Cleland, 1971) and that water stress reduces the final size of the epidermal cells (McCree and Davies, 1974). The present results show that poplar leaves follow the same pattern. The mean size of the cells was mainly reduced by water stress. Carbon nutrition specifically changes the number of epidermal cells. It can be concluded that cell divisions in an expanding leaf are limited by the carbon supply. In control plants, a regular increase in the size of the newly initiated leaves was observed. It could be explained by an increased carbon availability with the number of leaves of the young tree. The importance of this $\mathrm{CO}_{2}$ effect could be justified, considering that it increases the photosynthetic activity of growing leaves. Autotrophy of expanding leaves in poplar has been demonstrated (Larson et al., 1980) and carbon nutrition stimulation could be particularly significant by stimulating autotrophic carbon supply in young leaves.

\section{Acknowledgments}

This work was supported by the CNRS contract: Physiologie de la Croissance et du Développement des Végétaux ligneux.

\section{References}

Austin R.B., Morgan C.L., Ford M.A. \& Bhagwat S.G. (1982) Flag leaf photosynthesis of Triticum aestivum and related diploids and tetraploids species. Ann. Bot. 49, 177-189

Bouchon J. (1975) Précision des mesures de superficies par comptage de points. Ann. Sci. For. 32, 131-134.

Cleland R. (1971) Cell wall extension. Annu. Rev. Plant Physiol. 22, 197-222

Clough B.F. \& Milthorpe F.L. (1975) Effect of water deficit on leaf development in tobacco. Aust. J. Plant Physiol. 2, 291-300

Dale J.E. \& Milthorpe F.L. (1983) General features of the production and growth of leaves. In: The Growth and Functioning of Leaves. (Dale J.E. \& Milthorpe F.L., eds.), Cambridge University Press, Cambridge, pp. 151-178

Lapierre C., Gaudillère J.P., Guittet E., Rolando C. \& Lallemand J.Y. (1983) Enrichissement photosynthétique en carbone 13 de lignine de peuplier: caractérisation préliminaire par acidolyse et RMN ${ }^{13} \mathrm{C}$. Holzforschung 37, 217-224

Larson P.R., Isebrands J.G. \& Dickson R.E. (1980) Sink to source transition of Populus leaves. Ber. Dtsch. Bot. Ges. 93, 79-80

Lockhart J.A. (1965) An analysis of irreversible plant cell elongation. J. Theor. Biol. 8, 264-276

McCree K.J. \& Davies S.D. (1974) Effect of water stress and temperature on leaf size and on size and number of epidermal cells in grain sorghum. Crop Sci. 14, 751-755 